24. Falcao RP 1980 Human blood lymphocyte subpopulations from birth to eight years. Clin Exp Immunol 39:203-207

25. Mascart-Lemone F. Delespesse G, Servais G, Kunstler M 1982 Characterization of immunoregulatory $T$ lymphocytes during ageing by monoclonal antibodies. Clin Exp Immunol 48:148-154

26. Yachie A, Miyawaki T, Nagaoki T, Yokoi T, Mukai M, Uwadana N, Taniguchi N 1981 Regulation of B cell differentiation by $T$ cell subsets defined with monoclonal OKT4 and OKT8 antibodies in human cord blood. J Immunol 127:1314-1317

27. Moody CE, Innes JB, Staiano-Coico L, Incefy GS, Thaler HT, Weksler ME 1981 Lymphocyte transformation induced by autologous cells. XI. The effect of age on the autologous mixed lymphocyte reaction. Immunology 44:431438

28. Schwab R, Staiano-Coico L, Weksler ME 1983 Immunological studies of aging. IX. Quantitative differences in $\mathrm{T}$ lymphocyte subsets in young and old individuals. Diag Immunol 1:195-198

29. Nagel JE, Chrest FJ, Adler WH 1981 Enumeration of T lymphocyte subsets by monoclonal antibodies in young and aged humans. J Immunol 127:20862088

30. Bongers V, Bertrams J 1984 The influence of common variables on $\mathrm{T}$ cell subset analysis by monoclonal antibodies. J Immunol Methods 67:243-253

\title{
Announcements
}

\author{
Annual Meeting
}

The American Pediatric Society and The Society for Pediatric Research announce the abstract deadline for the 1987 Annual Meeting (April 27-May 1, Disneyland Hotel, Anaheim, CA) has been set as December 3, 1986.

For further information contact: SPT-Debbie L. Wogenrich, The Society for Pediatric Research, Department of Pediatrics, UNM School of Medicine, Albuquerque, NM 87131, (505) 277-6629 or APS-Dr. Audrey K. Brown, Secreatry-Treasurer, Department of Pediatrics, Box 49, SUNY, Health Sciences Center at Brooklyn, 450 Clarkson Avenue, Brooklyn, NY 11203, (718) $270-1692$.

\section{Pediatric Symposium}

The IIIrd International Symposium on Pediatric Surgical and Neonatal Intensive Care will be held September 15-18, 1987 at the Hotel Sofitel, Paris.

Congress President: G. Huault. President Organizing Committee: F. Beaufils. President Scientific Committee: M. Dehan.

Information: SOCFI-14, Rue Mandar-75002, Paris, France.

\section{9th Summer Program in Methods of Immunologic Research and Diagnosis}

This program is offered by the Ernest Witebsky Center for Immunology, University at Buffalo, State University of New York, June 7-20, 1987. It is a 2-wk program that consists of combinations of core and elective lectures, demonstrations, discussions, and practical laboratory exercises; participants personally carry out techniques at the bench. Open to postdoctoral level, supervisory senior technologists, and graduate students beyond the master's level.

For detailed program description contact James F. Mohn, M.D., Director, The Ernest Witebsky Center for Immunology, 210 Sherman Hall, Buffalo, New York 14214. (716) 831-2848. Inquiries should be received by 20 February 1987, to insure consideration for acceptance.

\section{Pediatric Respiratory Disease}

The National Heart, Lung, and Blood Institute, National Institutes of Health, has recently published an evaluation report on Pediatric Respiratory Disorders. This report relates to major advancements made in six categories of pediatric respiratory disorders and includes assessment of opportunities and needs in the epidemiology, diagnosis, management, and prevention of pediatric lung diseases. Copies of this report are available on request. Send reprint requests to Pushpa V. Thadani, Ph.D., Structure and Function Branch, DLD, NHLBI, Westwood Building, Room 6A07, Bethesda, MD 20892. 